\title{
Pensononowoor
}

2014, vol. 72, 41-46

http://dx.doi.org/10.12657/denbio.072.003

\author{
Cristian Mihai Enescu
}

\section{Sea-buckthorn: a species with a variety of uses, especially in land reclamation}

\author{
Received: 07 June 2013; Accepted 15 May 2014
}

\begin{abstract}
Sea-buckthorn is an important species especially in terms of land reclamation, but it has also an appreciable commercial value. The aim of this review paper was to highlight the multiple uses of this shrub species across world. Data regarding taxonomy, chorology, ecological requirements and biological characteristics were also presented. Special attention has been given to the role of sea-buckthorn in land reclamation. The importance of this species is expected to increase in the future due to its high ecological amplitude and biological characteristics that make it suitable for many types of land, including arid terrains.
\end{abstract}

Additional key words: Hippophaë rhamnoides, sea-buckthorn, land reclamation.

Address: C.M. Enescu, University of Agronomic Sciences and Veterinary Medicine, Faculty of Agriculture, Department of Soil Sciences, 59, Mărăști Blvd, 011464, Bucharest, Romania, e-mail: mihaienescu21@yahoo.com

\section{Introduction}

Genus Hippophaë L. $(2 \mathrm{n}=24)$ belongs to the family Elaeagnaceae (Kalia et al. 2011). The taxonomy of this genus has been a subject of debate among specialists regarding the exact number of species, in spite of many molecular, taxonomic and phylogenetic studies done (Aras et al. 2007). For example, according to Deepu et al. (2007), there are 6 species and 12 sub-species. The same number of species was proposed also by Ahmad and Kamal (2002), but Suryakumar and Gupta (2011) considered to be seven species. Among them, the most widespread species is Hippophaë rhamnoides L. (sea-buckthorn), which was divided in eight (Small et al. 2002) or nine subspecies (Rousi 1971). The generic name of sea-buckthorn originates from the Greek words hippo, which means horse and phaos, which means to shine. This was due to the fact that its leaves and young branches were used as fodder for horses, which gained rapidly in weight and their coat became shinier (Rongsen 1992).

Sea-buckthorn is a spinescent, deciduous and anemophilous shrub or a small tree (Vescan et al. 2010). Mature plants are extremely variable in height, from less than $50 \mathrm{~cm}$ to $20 \mathrm{~m}$ tall (Zeb and Khan 2008). Their usual height is ranging between 2 to 10 $\mathrm{m}$ (Rehder 1960). The bark is rough brown, the young branches are gray and usually spiny and the buds are alternate and golden-brown. The leaves are linear or linear-lanceolate, 2-6 cm long, with short petioles and entire margin, acutish, covered on both sides with silvery scales, often glabrescent above at maturity. The flowers are very small, yellowish, without petals and appear before the leaves. The fruit is subglobose to ovoid, 6-8 mm long, orange-yellow (Rehder 1960). 
According to a recent study (Kruczek et al. 2012), the differences in color might indicate differences in carotenoids and other compounds content.

\section{Distribution range}

H. rhamnoides is widely distributed throughout the temperate zone of Asia and Europe, between $27^{\circ}$ and $69^{\circ} \mathrm{N}$ latitude and $7^{\circ} \mathrm{W}$ and $122^{\circ} \mathrm{E}$ longitude (Rousi 1971). Two decades earlier, in China, Mongolia and Rusia, the total area of sea-buckthorn natural stands was about 810.000 ha, while the planted stands were around 300.000 to 500.000 ha (Sun 1995). H. rhamnoides has also an extremely wide distribution throughout the Indian Himalayas (Zeb 2004), where it grows naturally between $3000-5000 \mathrm{~m}$ a.s.l. (Raina et al. 2012).

\section{Ecological requirements}

Sea-buckthorn is a pioneer species, highly adaptable to extreme climatic and soil conditions. It is considered to be both frost resistant and drought resistant (Kondrashov and Sokolova 1990), being able to tolerate extremes of temperature, ranging from $-43^{\circ} \mathrm{C}$ to $+40^{\circ} \mathrm{C}$ (Ruan and $\mathrm{Li} 2002$ ), or $+45^{\circ} \mathrm{C}$ (Kumar and Sagar 2007), or even $+55^{\circ} \mathrm{C}$ (Sabir et al. 2003). In Romania, H. rhamnoides is considered to be the species with the greatest ecological amplitude (Brasovan and Codrea 2008).

It is a light demanding species (Bolibok et al. 2008). Sea-buckthorn is able to grow almost on all types of soils, even the degraded terrains (Acharya et al. 2010), being also adapted to the salinity and alkalinity (Bolibok et al. 2008). It can tolerate also the inundation (Ruan and Li 2002), but it prefers to grow in low humid, alluvial gravel, wet landslips and riverside.

\section{Biological characteristics}

In $H$. rhamnoides, fruit bearing begins at early ages, namely at 4-7 years old (Petrova et al. 2008) and it produces abundant fruit crops once at two years, their harvesting starting from August and continue till September or October (Georgescu et al. 2007).

Sea-buckthorn is an atmospheric nitrogen-fixing species. It was proven that this species has an efficient symbiotic relationship with a bacterium of the genus Frankia, which generally improves soil fertility (Jike and Xiaoming 1992; Brasovan and Codrea 2008). Furthermore, having caduceus leaves, the annual leaf-litter represents an important source of organic elements for soils (Brasovan et al. 2009).
H. rhamnoides can be propagated in both vegetative and generative ways. Propagation by seed is considered to be the simplest method. In general, the seeds do not require any special seed bed preparation ( $\mathrm{Li}$ and Wardle 1999). But in order to obtain high germination percentages some pre-treatments of the seeds can be applied. For example, it was demonstrated that by soaking the seeds in sulphuric acid for $1 \mathrm{~min}$ it resulted a $100 \%$ germination rate and a very short time before maximum germination rate, namely 4 days (Olmez 2011). According to Tylkowski (2010), in contrast to earlier studies, sea-buckthorn seeds proved to be non-dormant, reason why seedling emergence in the open nursery could be risky. In order to avoid this problem, spring sowing in the greenhouse is recommended (Tylkowski 2010). On the other hand, sea-buckthorn is able to produce stump and root sprouts very easily, starting from 3 to 5 years old (Traci 1988).

\section{Sea-buckthorn: a multipurpose species}

Due to its large spectrum of uses (ecological, nutritional, ornamental, therapeutic a.s.o.) sea-buckthorn is a genuine multipurpose species of great importance worldwide (Vescan et al. 2010). Especially thanks to its very wide ecological amplitude, easy propagation, and other uses, sea-buckthorn has been used intensively for the establishment of productive and protective plantations.

Firstly, by being famous for its ability to grow under almost any edaphic conditions and to colonize bare terrains, it plays an important role in land reclamation, being able to provide a very high protection to the soil (Bolea and Chira 2012). Together with pine species, larch, black locust, alder species, sycamore maple, Manna ash, silver berry and wild privet, sea-buckthorn is nowadays one of the most important and used shrub species for land reclamation. For example, sea-buckthorn is suitable for reclamation of coal ash before reforestation (Čermák 2008), for preventing or checking soil erosion (Small et al. 2002; Sabir et al. 2003), for fast substratum stabilization (Bolibok et al. 2008), for ameliorating sandy soils affected by wind erosion (Van der Putten et al. 1993) or afforestation of salty lands (Chen et al. 2009) and for ecological reconstruction (Blaj et al. 2009; Covaci et al. 2009). It was even used for combating the desertification (Heshmati 2011), being able to grow alone or in association with other shrub species (e.g. saltcedar or silver berry) on high dunes (Strat 2005). Sea-buckthorn is preferred in these site conditions due to its capacity to invade sand dunes, like it was reported even in Ireland (Cross 2006). Moreover, regarding the soil physical conditions, it was demonstrated that 
these are better in a mixed forest with sea-buckthorn than in a pure one (Zhang and Chen 2007).

Secondly, H. rhamnoides is appreciated especially for its berries which are very rich in vitamins (Zeb 2004), but also for oil, leaves and bark extracts, hundreds of products being developed and used in different purposes, such as producing juice, alcoholic beverages, tea, candies, food colors, or medicines and shampoos (Wu 1991) or cosmetics, such as sun care cosmetics and anti-aging skin creams and lotions (Parimelazhagan et al. 2004). Moreover, it have been shown that its berries contain much higher concentrations of vitamins A, B2, C than carrot, tomato or orange (Zeb 2004). It is known that by consuming the berries in the morning, before the breakfast, the human body is becoming stronger and the aging is delayed (Cireașă et al. 2005). According to a recent study (Ahmad and Ali 2013), sea-buckthorn leaves can represent a very rich source of several minerals and proteins for humans. It can be stated that all parts of this species contain very useful bioactive components (Christaki 2012), but these can vary with fruit size and maturity or climate conditions (Leskinen et al. 2010). In medicine, the Hippophae oil is used in therapy of tumors, gastric or gynecological diseases (Albulescu et al. 2006) or skin dermatitis (Brad et al. 2007, Verma et al. 2013). Regarding the latter example, it was reported that the antioxidant emulsion of sea-buckthorn can significantly improve the skin biomechanical parameters after a seven weeks treatment (Khan et al. 2012). Furthermore, it provides several benefits to the cerebral-cardiovascular health and to the immune system (Kumar at al. 2011).

Thirdly, sea-buckthorn bushes, beside their land reclamation and other uses, can provide an excellent habitat to several wildlife species (Acharya et al. 2010), being both shelter and winter food (the fruit persist all winter long) for several bird or small mammals species (Binggeli et al. 1992). Moreover, its leaves which have considerable amount of proteins can be used as livestock and pet food (Suryakumar and Gupta 2011).

Last but not least, $H$. rhamnoides can be used as an ornamental shrub species (Li and Schroeder 1996) thanks to its silver leaves and orange berries, being planted alone or in hedges. Moreover, it is also very appreciated in apiculture (Cimpoiu et al. 2013).

\section{Sea-buckthorn: drawbacks}

A shortcoming of sea-buckthorn is represented by the lack of an efficient method able to differentiate the female and male individuals in order to assure the favorable sex ratio if, for example, someone plans to install a crop (Truta et al. 2011). In order to resolve this problem, vegetative propagation from mature plants with known sex should be applied. According to some recommendations, the male individuals proportion adequate for pollination should vary from $6 \%-7 \%$ (Gakov 1980) to $8 \%-12 \%$ (Albrecht et al. 1984).

Developing of thorns (2-5 cm long) at early ages (2-3 years old) represents another drawback of $H$. rhamnoides. This specific feature is unwanted if harvesting is done by hand. Hopefully, by the aid of breeding programs new genotypes without thorns, but with higher fruit size, yield, and oil content would be obtained (Li 2002).

Nowadays, since sea-buckthorn is a new cultivated crop, some damaging insects, such as green aphids, gypsy moth, fruit fly or caterpillars, were reported. This is due the low number of registered pesticides and fungicides for this species (Li 2002).

Even if this species is very appreciated and used in land reclamation, negative impacts on sand dune ecosystems were reported. This was mainly due to the fact that sea-buckthorn replaced botanically interesting plant communities and invaded dune habitats, thanks to its very fast vegetative propagation, reason for which a long-term management should be applied (Binggeli et al. 1992). This replacement could represent a limiting factor to stand and site biodiversity. According to Daehler (1998), rapid vegetative propagation and nitrogen fixation represent indicators of plant invasiveness. As a result, sea-buckthorn is regarded as one of the most aggressive invasive shrub species across the world.

\section{Conclusions}

The invasive behavior of sea-buckthorn, its extensive use in several areas and the intensive efforts to reclaim and ameliorate different types of terrains affected especially by water or wind erosion with this species in many regions worldwide, have lead to its spread and naturalization on large areas.

According to this brief literature review, $\mathrm{H}$. rhamnoides should be regarded more as a very useful multi-purpose shrub species with a high potential for forest land reclamation, rather than a dangerous invasive one. Nevertheless, the presence of this species should be carefully monitored around fragile landscapes in nutrient-poor and dry locations, as it has potential to do great harm.

The experience acquired in land reclamation with sea-buckthorn is very important from the perspective of global warming. It is expected that the importance of this species will increase in the future due to its high ecological amplitude and biological characteristics that make it suitable even for arid lands. 
As a final conclusion, sea-buckthorn represents a wonder plant, which provides several benefits to humanity.

\section{References}

Acharya S., Stobdan T., Singh S.B. 2010. Seabuckthorn (Hippophaë sp. L.): New crop opportunity for biodiversity conservation in cold arid Trans-Himalayas. Journal of Soil and Water Conservation 9: 201-204.

Ahmad S.D., Kamal M. 2002. Morpho-molecular Characterization of local Genotypes of Hippophä̈ rhamnoides L. ssp. Turkestanica a Multipurpose Plant from Northern Areas of Pakistan. Online Journal of Biological Sciences 2: 351-354. http:// dx.doi.org/10.3923/jbs.2002.351.354

Ahmad B., Ali J. 2013. Physiochemical, minerals, phytochemical contents, antimicrobial activities evaluation and fourier transform infrared (FTIR) analysis of Hippophaë rhamnoides L. leaves extracts. African Journal of Pharmacy and Pharmacology 7: 375-388. http://dx.doi.org/10.5897/ AJPP12.1246

Albulescu M., Gruia A., Modra D. 2006. Preliminary research on sea buckthorn (Hippophaë rhamnoides) oil obtaining. Annals of West University of Timișoara, Series Chemistry 15: 187-192.

Albrecht H.J., Gerber J., Koch H.J., Wolf D. 1984. Experience in growing sea buckthorn. Gartenbau 31: 242-244.

Aras A., Akkemik U., Kaya Z. 2007. Hippophaë rhamnoides L.: fruit and seed morphology and its taxonomic problems in Turkey. Pakistan Journal of Botany 39: 1907-1916.

Binggeli P., Eakin M., Macfadyen A., Power J., McConnell J. 1992. Impact of the alien sea buckthorn (Hippophaë rhamnoides L.) on sand dune ecosystems in Ireland. In: Coastal Dunes, Carter, Curtis \& Sheehy-Skeffington (eds.), Rotterdam, p. 325-337.

Blaj R., Mărginean M., Stanciu M. 2009. Aspects regarding to ecological reconstruction at Copșa Mică, Sibiu County. Research Journal of Agricultural Sciences 41: 23-28.

Bolea V., Chira D. 2012. Perdele forestiere de protecție antifonică și antipoluantă pe perimetrul companiei Kronospan România. Revista de Silvicultură și Cinegetică 30: 78-87.

Bolibok L., Kowalczyk M., Szeligowski H. 2008. The influence of substratum $\mathrm{pH}$ level on growth of sea buckthorn (Hippophaë rhamnoides L.) of the external spoil bank of the Bełchatów Brown coal mine. Acta Scientiarum Polonorum. Silvarum Colendarum Ratio et Industria Lignaria 7: 5-12.

Brad I., Vlăsceanu G.A., Brad I.L., Manea St. 2007. Characterization of sea buckthorn fruits and cops- es in terms of serotonin and microelements. Innovative Romanian Food Biotechnology 1: 24-30.

Brasovan A., Codrea V. 2008. Data on coal dumps retrieving in Petrosani basin using sea buckthorn (Hippophaë rhamnoides). Analele Universitatii din Oradea, Fascicula Biologie 15: 17-21.

Brasovan A., Codrea V., Mândroc V., Câmpean R., Olah N. 2009. The content determination of calcium, magnesium and ascorbic acid in sea buckthorn fruits at Vulcan coal dump. Analele Universității din Oradea, Fascicula Biologie 16: 40-42.

Čermák P. 2008. Forest reclamation of dumpsites of coal combustion by-products (CCB). Journal of Forest Science 54: 273-280.

Chen W., Cui P., Sun H., Guo W., Yang C., Jin H., Fang B., Shi D. 2009. Comparative effects of salt and alkali stresses on organic acid accumulation and ionic balance of seabuckthorn (Hippophaë rhamnoides L.). Industrial Crops and Products 30: 351-358. http://dx.doi.org/10.1016/j.indcrop.2009.06.007

Christaki E. 2012. Hippophaë rhamnoides L. (Sea Buckthorn): a Potential Source of Nutraceuticals. Food and Public Health 2: 69-72. http://dx.doi. org/10.5923/j.fph.20120203.02

Cimpoiu C., Hosu A., Miclaus V., Puscas A. 2013. Determination of the floral origin of some Romanian honeys on the basis of physical and biochemical properties. Spectrochimica Acta Part A: Molecular and Biomolecular Spectroscopy 100: 149-154. http://dx.doi.org/10.1016/j.saa.2012.04.008

Cireașă V., Gavrilescu C.M., Pădureanu S. 2005. Pomopsihoterapia, știința mileniului III. Universitatea de Științe Agricole și Medicină Veterinară "Ion Ionescu de la Brad" Iași, Lucrări Științifice, Seria Horticultură 2: 23-26.

Covaci C., Rogobete Gh., Lazarovici M., Covaci D. 2009. Ecological reconstruction of forest land in the area of Sichevita, Caras-Severin County. Research Journal of Agricultural Sciences 41: 61-66.

Cross J.R. 2006. The potential natural vegetation of Ireland. Biology and Environment: Proceedings of the Royal Irish Academy 106: 65-116. http://dx. doi.org/10.3318/BIOE.2006.106.2.65

Daehler C.C. 1998. The taxonomic distribution of invasive angiosperm plants: ecological insights and comparison to agricultural weeds. Biological Conservation 84: 167-180. http://dx.doi. org/10.1016/S0006-3207(97)00096-7

Deepu M., Parimelazhagan T., Gomez S., Ahmed Z. 2007. Characterization of Seabuckthorn (Hippophaë spp.) genetic resources in India using morphological descriptors. Plant Genetic Resources Newsletter 149: 22-26.

Gakov M.A. 1980. Prospects for the development of Hippophaë rhamnoides in the Tuva, ASSR. Lesnoe Khozyaistvo 2: 51-52. 
Georgescu C., Crăciun I., Bratu I., Turtureanu A. 2007. The quantitative analysis of flavonoid compounds in the species of Teucrium chamaerys and Hippophä rhamnoides. Journal of Agroalimentary Processes and Technologies 1: 139-142.

Heshmati G.A. 2011. Biological Models for Protecting Different Land Use in Arid Areas in China. Journal of Rangeland Science 1: 235-246.

Jike Z., Xiaoming Z. 1992. Progress of study on Frankia in nodules of Seabuckthorn. Hippophae 2: 4-10.

Kalia R.K., Singh R., Rai M.K., Mishra G.P., Singh S.R., Dhawan A.K. 2011. Biotechnological interventions in sea buckthorn (Hippophä̈ L.): current status and future prospects. Trees 25: 559-575. http://dx.doi.org/10.1007/s00468-011-0543-0

Khan B.A., Akhtar N., Braga V.A. 2012. Anti-Aging Effects of Hippophaë rhamnoides Emulsion on $\mathrm{Hu}-$ man Skin. Tropical Journal of Pharmaceutical Research 11: 955-962.

Kondrashov V.T., Sokolova E.P. 1990. New wilt-resistant forms of Hippophä̈ rhamnoides. Byulleten Moskovskogo Obshchestva Ispytatelei Prirody Biologicheskii 96: 146-153.

Kruczek M., Świderski A., Mech-Nowak A., Król K. 2012. Antioxidant capacity of crude extracts containing carotenoids from the berries of various cultivars of Sea buckthorn (Hippophaë rhamnoides L.). Acta Biochimica Polonica 59: 135-137.

Kumar S., Sagar A. 2007. Microbial associates of Hippophaërhamnoides (Seabuckthorn). Plant Pathology Journal 6: 299-305. http://dx.doi.org/10.3923/ ppj.2007.299.305

Kumar R., Kumar G.P., Chaurasia O.P., Singh S.B. 2011. Phytochemical and Pharmacological Profile of Seabuckthorn Oil: A Review. Research Journal of Medicinal Plant 5: 491-499. http://dx.doi. org/10.3923/rjmp.2011.491.499

Leskinen H.M., Suomela J.P., Yang B., Kallio H.P. 2010. Regioisomer compositions of vaccenic and oleic acid containing triacyglycerols in sea buckthorn (Hippophä̈ rhamnoides) pulp oils: influence of origin and weather conditions. Journal of Agriculture and Food Chemistry 58: 537-545. http:// dx.doi.org/10.1021/jf902679v

Li T.S.C., Schroeder W.R. 1996. Sea Buckthorn (Hippophä̈ rhamnoides L.): A Multipurpose Plant. HortTechnology 6: 370-380.

Li T.S.C. 2002. Product Development of Sea Buckthorn. In: Trends in New Crops and New Uses. J. Jani and A. Whipkey (eds.) ASHS Press, Alexandria, VA: 393-398.

Li T.S.C., Wardle D.A. 1999. Effects of Seed Treatments and Planting Depth on Emergence of Sea Buckthorn Species. HortTechnology 9: 213-216.

Olmez Z. 2011. Effects of cold stratification and $\mathrm{H}_{2} \mathrm{SO}_{4}$ on seed germination of sea buckthorn
(Hippophaë rhamnoides L.). African Journal of Biotechnology 10: 4586-4590.

Parimelazhagan T., Chourasia O.P., Raut B. 2004. Bio-active substances of Seabuckthorn. In: Souvenir and book of abstracts. National Seminar on cultivation, harvesting and scientific exploitation of Seabuckthorn. Field Research Laboratory (DRDO) India, 26-27 August, p.34.

Petrova A., Danova K., Kapchina-Toteva V. 2008. Ecological evaluation and conservational value for Bulgaria of Hippophä rhamnoides L. Total flavonoids determination and experiments on in vitro culture induction. Comptes rendus de l'Académie bulgare des Sciences 61: 363-370.

Raina S.N., Jain S., Sehgal D., Kumar A., Dar T.H., Bhat V., Pandey V., Vaishnavi S., Bhargav A., Singh V., Rani V., Tandon R., Tewari M., Mahmoudi A. 2012. Diversity and relationships of multipurpose sea buckthorn (Hippophaë L.) germplast from the Indian Himalayas as assessed by AFLP and SAMPL markers. Genetic Resources and Crop Evolution 59: 1033-1053. http://dx.doi.org/10.1007/ s10722-011-9742-1

Rehder A. 1960. Manual of cultivated trees and shrubs - second edition. Macmillan Company, New York.

Rongsen A. 1992. Sea buckthorn a multi-purpose plant species for fragile mountains. ICIMOD Occasional Paper NO. 20, Khathmandou, p. 62.

Rousi A. 1971. The genus Hippophä̈ L. A taxonomic study. Annales Botanici Fennici 8: 177-227.

Ruan C., Li D.Q. 2002. Analysis on the community characteristics of Hippophä rhamnoides L. plantation and water and nutrition of woodland in Loess Hilly Region. Journal of Applied Ecology 13: 1061-1063.

Sabir S.M., Ahmed S.D., Lodhi N. 2003. Morphological and biochemical variation in Sea buckthorn Hippophä rhamnoides ssp. turkestanica, a multipurpose plant for fragile mountains of Pakistan. South African Journal of Botany 69: 587-592.

Small E., Catling P.M., Li T.S.C. 2002. Blossoming treasures of biodiversity: 5. Sea buckthorn (Hippophaë rhamnoides) - an ancient crop with modern virtues. Biodiversity 3: 25-27. http://dx.doi.org/ 10.1080/14888386.2002.9712575

Strat D. 2005. Beach and sand dune species plant of deltaic shore between Cape Buival-Câșla Vădanei (Sărăturile marine field). Revista de geomorfologie 7: 51-60.

Sun Z. 1995. Exploitation and utilization of Sea Buckthorn (H. rhamnoides L.) in China. NorthWest Univ.Publication, ShiAn, China.

Suryakumar G., Gupta A. 2011. Medicinal and therapeutic potential of Sea buckthorn (Hippophä rhamnoides L.). Journal of Ethnopharmacolo- 
gy 138: 268-278. http://dx.doi.org/10.1016/j. jep.2011.09.024

Traci C. 1988. Cătina albă (Hippophaë rhamnoides L.). Pentru o nouă orientare în cultura ei pe terenurile degradate și în conducerea cătinişurilor naturale și cultivate, din fondul forestier. Revista Pădurilor 103: 114-118.

Truta E., Capraru E., Rosu C.M., Zamfirache M.M., Olteanu Z., Manzu C. 2011. Morphometric pattern of somatic chromosomes in three Romanian Seabuckthorn genotypes. Caryologia 64: 189196. http://dx.doi.org/10.1080/00087114.2002. 10589783

Tylkowski T. 2010. Seed germination and seedling emergence in Hippophaë rhamnoides L. Dendrobiology 63: 53-58.

Van der Putten W.H., Van Dijk C., Peters B.A.M. 1993. Plant-specific soil-borne diseases contribute to succession in foredune vegetation. Nature 362: 53-56. http://dx.doi.org/10.1038/362053a0

Verma H., Sharma M., Chahota R., Palial A. 2013. Assessment of antimycotic activity of Seabuckthorn (Hippophaë rhamnoides) leaf exacts against common fungi associated with skin dermatitis. Veterinary World 6: 205-208. http://dx.doi. org/10.5455/vetworld.2013.205-208

Vescan A., Pamfil D., Bele C., Matea C., Sisea C.R. 2010. Several Lipophilic Components of Five Elite Genotypes of Romanian Seabuckthorn (Hippophä̈ rhamnoides subs. carpatica). Notulae Botanicae Horti Agrobotanici Cluj-Napoca 38: 114-122.

Wu F. 1991. Sea buckthorn medicine in Russia. Sea Buckthorn 4: 38-41.

Zeb A. 2004. Chemical and nutritional constituents of sea buckthorn juice. Pakistan Journal of Nutrition 3: 99-106. http://dx.doi.org/10.3923/ pjn.2004.99.106

Zeb A., Khan I. 2008. Pharmacological applications of sea buckthorn (Hippophaë). In: Eddouks M (Eds.) Advances in phytotheraphy research. Res Signpost, New Delhi.

Zhang J.-T., Chen T. 2007. Effects of mixed Hippophä̈ rhamnoides on community and soil in planted forests in the Eastern Loess Plateau, China. Ecological Engineering 31: 115-121. http://dx.doi. org/10.1016/j.ecoleng.2007.06.003 